Article

\title{
Evaluation of TRMM Product for Monitoring Drought in the Kelantan River Basin, Malaysia
}

\author{
Mou Leong Tan ${ }^{1, *}$, Kok Chooi Tan ${ }^{2}$, Vivien P. Chua ${ }^{1}$ and Ngai Weng Chan ${ }^{3}$ \\ 1 Department of Civil and Environmental Engineering, National University of Singapore, \\ Singapore 117576, Singapore; vivienchua@nus.edu.sg \\ 2 School of Physics, Universiti Sains Malaysia, 11800 Penang, Malaysia; kctan@usm.my \\ 3 Geography Section, School of Humanities, Universiti Sains Malaysia, 11800 Penang, Malaysia; \\ nwchan@usm.my \\ * Correspondence: mouleong@gmail.com or ceetml@nus.edu.sg; Tel.: +65-6516-2179
}

Academic Editors: Yunqing Xuan, Harshinie Karunarathna and Adrián Pedrozo-Acuña Received: 4 November 2016; Accepted: 10 January 2017; Published: 17 January 2017

\begin{abstract}
Assessment of satellite precipitation products' capability for monitoring drought is relatively new in tropical regions. The purpose of this paper is to evaluate the reliability of the Tropical Rainfall Measuring Mission (TRMM) Multisatellite Precipitation Analysis (TMPA) 3B43 product in estimating the standardized precipitation index (SPI) in the Kelantan River Basin, Malaysia from 1998 to 2014, by comparing it with data from 42 rain gauges. Overall, the TMPA-3B43 performed well in the monthly precipitation estimation, but performed moderately in the seasonal scale. Better performance was found in the northeast monsoon (wet season) than in the southwest monsoon (dry season). The product is more reliable in the northern and north-eastern regions (coastal zone) compared to the central, southern and south-eastern regions (mountainous area). For drought assessment, the correlations between the TMPA-3B43 and ground observations are moderate at various time-scales (one to twelve months), with better performance at shorter time-scales. The TMPA-3B43 shows similar temporal drought behavior by capturing most of the drought events at various time-scales, except for the 2008-2009 drought. These findings show that the TMPA-3B43 is not suitable to be used directly for SPI estimation in this basin. More bias correction and algorithm improvement work are needed to improve the accuracy of the TMPA-3B43 in drought monitoring.
\end{abstract}

Keywords: drought; TRMM; SPI; precipitation; Kelantan; Malaysia; tropical

\section{Introduction}

Drought is a temporary dry period ranging from months to years over a region, which could affect the environment, economy and society. Almost every part of the world has experienced drought, including the tropical regions [1]. These tropical regions are characterized by high annual precipitation, but a strong seasonality in precipitation could lead to drought conditions [2]. In recent years, research on tropical droughts has received substantial attention from researchers and policy makers due to the awareness on climate change [3-6]. For instance, occurrences of the 2010 Amazon drought [7], the 1997-1998 Malaysia drought [8], the 2015 Indonesia drought [9] and the 2012 Northeast Brazil drought [10] have turned the tropical forest from a net carbon sink to a source, thus impacting local communities and ecosystems.

Lack of precipitation is one of the main factors contributing to drought through a prolonged deficient precipitation period. As recommended by the World Meteorological Organization (WMO), the Standardized Precipitation Index (SPI) that requires only precipitation data as input has been widely used due to its simplicity and flexible time-scale computation [11]. Hence, accurate long-term precipitation data is fundamental in drought monitoring and analysis. Generally, the SPI is computed 
from rain gauge observations [12-15]. However, reliable ground-based precipitation measurements are difficult to obtain in many regions because of the sparse and irregular distribution of rain gauges. This situation is particularly acute in developing countries, with limited funds for rain gauge installation and maintenance.

Satellite precipitation products (SPPs) with high spatial and temporal scales are regarded as an alternative to ground-based precipitation information [16]. In addition, these products are open access and available in different time-steps (e.g., monthly, daily and hourly). They play an important role in national, regional and global precipitation monitoring as they are without data void problems in areas for which there are no ground-based observations. However, SPPs are affected by systematic and random error, missing seasonal variation and are inconsistent in drought events estimation [17,18]. Nevertheless, the SPPs' reliability in measuring precipitation is different from place to place due to retrieval algorithms, climate and topography conditions. Hence, many studies have been conducted to validate the SPPs in precipitation estimation with ground-based observations [19-21]. The SPPs' sensor and algorithm developers could understand these errors for developing better products in the future.

Tropical Rainfall Measuring Mission (TRMM) Multisatellite Precipitation Analysis (TMPA) products are among the popular SPPs that are widely used in hydro-climatic applications, e.g., flood forecasting, drought monitoring and hydrological modeling. The TRMM products are beneficial with moderate time-period (1998 to present), near-global coverage, high spatial $\left(0.25^{\circ} \mathrm{C}\right)$ and temporal (up to 3-hourly) resolution. Tao et al. [22] and de Jesus et al. [23] evaluated the reliability of the TRMM products in monitoring drought using SPI over the Jiangsu Province in China and in Mexico, respectively. Similar studies have also been conducted at basin-scale such as the Poyang Lake Basin [24] and the Lancang River Basin [25] in China and the Lake Chad Basin [26] in Africa. These studies concluded that TRMM products at monthly scale are quite suitable to monitor meteorological drought. However, there is relatively little performance evaluation of TRMM products for drought monitoring in tropical regions [27-29], particularly in Southeast Asia.

The aim of this study is to evaluate the reliability of the TMPA-3B43 product for drought monitoring in the Kelantan River Basin (KRB), Malaysia. The basin is selected as it is a typical tropical basin, but several major droughts have, nevertheless, occurred due to the El Niño effect. This study attempts to answer the question, is the TMPA-3B43 reliable to monitor tropical droughts? The main specific objectives are (1) to validate the TMPA-3B43 monthly and seasonal precipitation with ground-based observations from 1998 to 2014; (2) to compare the TRMM-based SPI and ground-based SPI; and (3) to analyze the drought patterns that occurred in the KRB during 2014. The findings will provide valuable information of the TMPA-3B43 in monitoring tropical drought to the TRMM users, producers and algorithm developers. This study presents the first attempt to evaluate the capability of TRMM product in measuring SPI in this tropical basin. Besides that, this study can also act as a reference to develop a cost-effective drought monitoring system in tropical regions.

\section{Study Area}

The KRB is situated in the north-eastern Peninsular Malaysia between $4^{\circ} \sim 6^{\circ} \mathrm{N}$ and $101^{\circ} \sim 103^{\circ} \mathrm{E}$ (Figure 1). The catchment area of the KRB is about $12,000 \mathrm{~km}^{2}$, which is equivalent to $85 \%$ of the Kelantan Province. The basin is dominated by forests $(76 \%)$, followed by rubber plantation (11\%), oil palm plantation (11\%) and other land-uses (2\%) in 2008, based on the Ministry of Agriculture and Agro-based Industry Malaysia. Elevations within the KRB range from 8 to $2174 \mathrm{~m}$ [30], with mountains in the western and south-western regions of the basin. The KRB has a tropical climate, with abundant precipitation throughout the year, ranging from about 2000 to $4000 \mathrm{~mm} /$ year (based on annual mean precipitation from 42 rain gauges). The basin receives heavy precipitation during the northeast monsoon (NEM) in November to January, while the southwest monsoon (SWM) brings less precipitation between May and August. The total population of the KRB is about 1.8 million in 2016. Several major drought events occurred in 1997, 1998, 2002, 2003, 2005, 2006, 2007, 2009 and 2010 [31,32]. 
These adverse events have urged the development of better drought analysis and monitoring systems to reduce the impacts of drought.

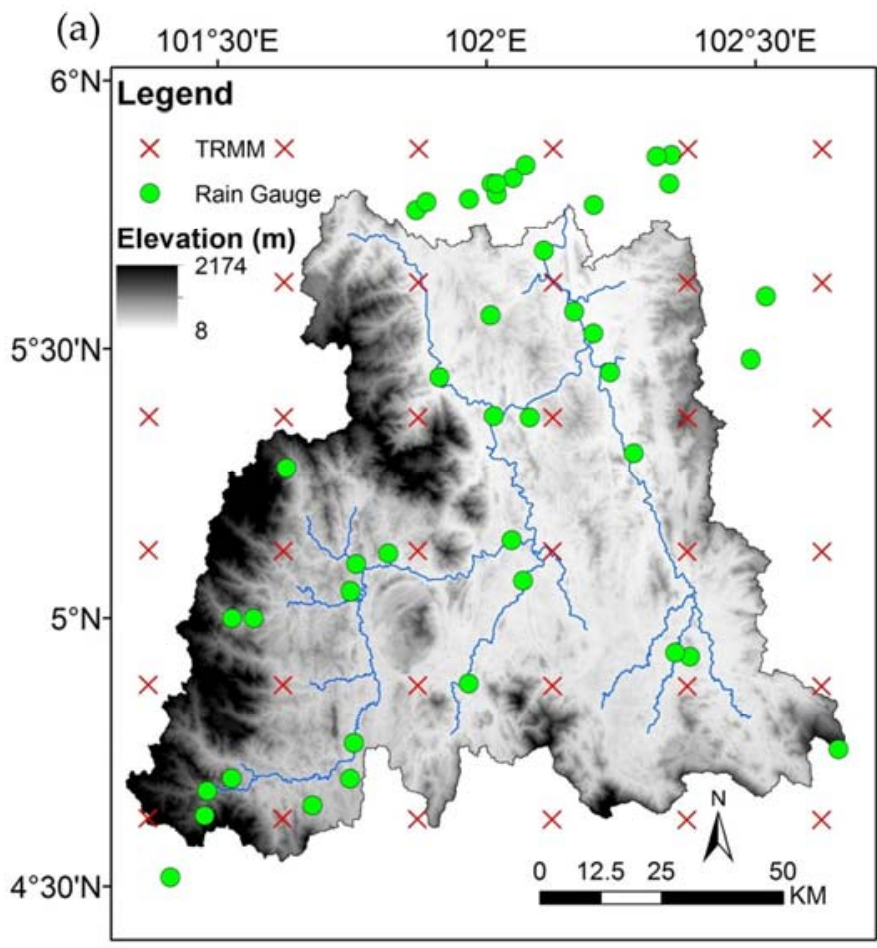

(b)
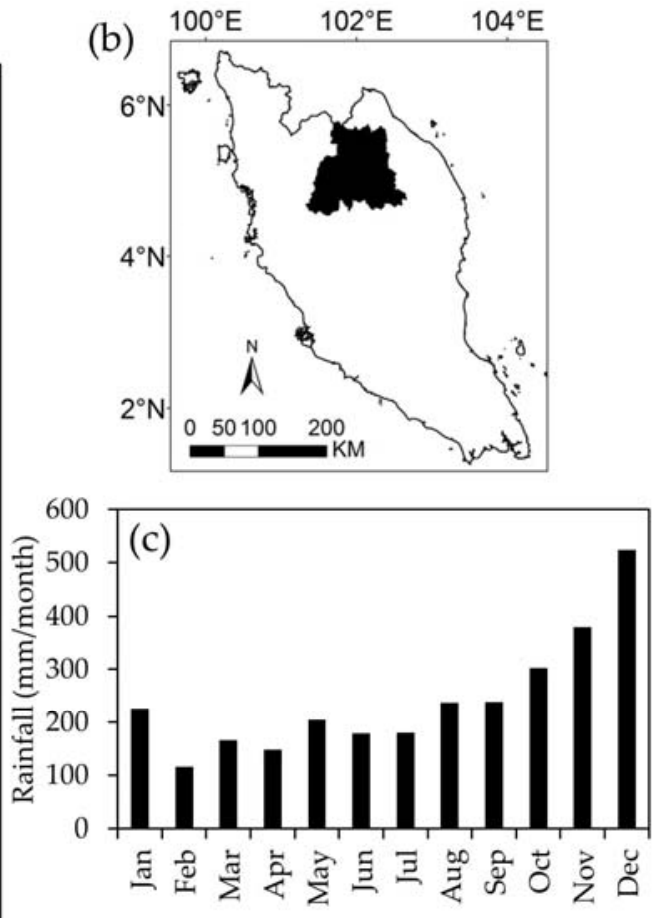

Figure 1. (a) Kelantan River Basin, (b) Peninsular Malaysia and (c) monthly mean precipitation from 1998 to 2014.

\section{Materials and Methods}

\subsection{Precipitation Data}

The TRMM mission is a collaboration between the Japan Aerospace Exploration Agency (JAXA) and the National Aeronautics and Space Administration (NASA) to monitor precipitation in tropical and sub-tropical regions. The latest TRMM TMPA version 7 contains three precipitation products at different temporal resolutions, including 3B42RT (3-hourly), 3B42 (daily), and 3B43 (monthly). Precipitation information of these products is available from 1998 to present, with a spatial resolution of $0.25^{\circ} \times 0.25^{\circ}$ that covers a latitude from $50^{\circ} \mathrm{S}$ to $50^{\circ} \mathrm{N}$. The TRMM $3 \mathrm{~B} 42$ and $3 \mathrm{~B} 43$ products are more accurate products than real time products (3B42RT) as they were corrected using the Global Precipitation Climatology Centre (GPCC) gauge-based gridded monthly precipitation prior to public release. Malaysia only contributed 37 rain gauges covering both Peninsular Malaysia and East Malaysia for the GPCC product development [33]. Therefore, many rain gauges are excluded from the TMPA-3B43 bias correction, justifying the independent validation in this study. More details about TMPA algorithms are given by Huffman et al. [34]. All TRMM products are freely available from Goddard Earth Sciences Data and Information Services Center at [35]. In the present work, the monthly precipitation TRMM images from 1998 to 2014 were used. There are 36 grid points covering the KRB as shown in Figure 1 and Supplementary Table S1. The precipitation rates $(\mathrm{mm} / \mathrm{h})$ were converted into monthly precipitation amounts by multiplying total hours in that month (e.g., multiply by 744 for January).

The historical daily precipitation data (1998-2014) of 42 rain gauges were obtained from the Malaysian Meteorological Department (MMD) and Department of Irrigation and Drainage Malaysia (DID) (Figure 1 and Supplementary Table S2). The daily precipitation values for both MMD and DID were taken at 00:00 Universal Time Coordinated (UTC) (8 a.m. local time). These rain gauges were 
selected due to their low quantity of missing data (less than 10\%). The missing values were filled with the precipitation values from the nearest stations. Then, the daily precipitation was aggregated into a monthly scale for better comparison.

\subsection{Standardized Precipitation Index}

SPI is a quantitative measure of drought level by assimilating precipitation into a single number, and is more useful in drought monitoring. It is developed by Mckee et al. [11] based on the goodness-of-fit of the observed precipitation to a probability distribution such as the Gamma probability density function or Pearson type III. It can be computed at different time-scales from 1 to 24 months. In this study, the comparison was focused on SPI-1, SPI-3, SPI-6 and SPI-12, corresponding to the past 1, 3, 6 and 12 months of total precipitation, respectively. Generally, the values of SPI vary from 3 to -3 with positive values showing wet conditions and negative values showing dry conditions. The dryness and wetness conditions are then divided into seven classes as listed in Table 1. The SPI program is freely available from the National Drought Mitigation Center at [36].

Table 1. Standardized Precipitation Index (SPI) categories.

\begin{tabular}{cc}
\hline Class & SPI Value \\
\hline extremely wet & SPI $\geq 2$ \\
severely wet & $1.5 \leq \mathrm{SPI}<2$ \\
moderately wet & $1 \leq \mathrm{SPI}<1.5$ \\
near-normal & $-1<\mathrm{SPI}<1$ \\
moderately dry & $-1.5<\mathrm{SPI} \leq-1$ \\
severely dry & $-2<\mathrm{SPI} \leq-1.5$ \\
extremely dry & $\leq-2$ \\
\hline
\end{tabular}

\subsection{Validation Process}

The accuracy of the TMPA-3B43 was validated at monthly and seasonal time-scales by comparing with 42 rain gauges that were well distributed over the basin. The comparisons between the TMPA-3B43 and rain gauge data were carried out by a point-to-pixel approach [16,37-39]. This approach is selected to avoid any additional errors and uncertainties during the interpolation process from rain gauges. Hence, only the pixels that contain at least one rain gauge were considered.

The overall assessment performance of the TMPA-3B43 was evaluated by pooling all the precipitation values from the 42 rain gauges for the period of 1998-2014, and then comparing with their respective grid points $[40,41]$. For seasonal analysis, the precipitation was divided into four seasons, which are December to February (DJF), March to May (MAM), June to August (JJA) and September to November (SON) [42]. This resulted in 8568 monthly totals and 714 seasonal totals (for four seasons) over the 42 rain gauges for the 17 years study period.

\subsection{Statistical Analysis}

A series of popular statistical metrics such as root mean square error (RMSE), Pearson linear correlation coefficient $(\mathrm{R})$ and relative bias (Bias) are used in this study as listed in Table $2[22,39,43,44]$. The RMSE measures the magnitude of the difference between two variables (e.g., observed precipitation and TMPA-3B43 precipitation). The $\mathrm{R}$ is widely applied to evaluate how well the two variables agree, with the values ranging from -1 to 1 . A strong positive linear correlation is found, if the $R$ value is close to 1 and vice-versa. The systematic bias of the TMPA-3B43 in percentage (\%) was evaluated using the bias algorithm. A good performance should be characterized by low RMSE and bias, and high $\mathrm{R}$ values. 
Table 2. Statistical metrics ( $\mathrm{T}=\mathrm{TMPA}-3 \mathrm{~B} 43 ; \mathrm{O}=$ Observed value).

\begin{tabular}{cc}
\hline Methods/Unit & Equation \\
\hline Root Mean Square Error (RMSE)/mm & RMSE $=\sqrt{\frac{1}{n} \sum_{i=1}^{n}\left(T_{i}-O_{i}\right)^{2}}$ \\
\hline Pearson Linear Correlation Coefficient (R) & $\mathrm{R}=\frac{\sum_{\mathrm{i}=1}^{\mathrm{n}}\left(\mathrm{O}_{\mathrm{i}}-\overline{\mathrm{O}}\right)\left(\mathrm{T}_{\mathrm{i}}-\overline{\mathrm{T}}\right)}{\sqrt{\sum_{\mathrm{i}=1}^{\mathrm{n}}\left(\mathrm{O}_{\mathrm{i}}-\overline{\mathrm{O}}\right)^{2}} \cdot \sqrt{\sum_{\mathrm{i}=1}^{\mathrm{n}}\left(\mathrm{T}_{\mathrm{i}}-\overline{\mathrm{T}}\right)^{2}}}$ \\
\hline Relative Bias (Bias) $/ \%$ & $\mathrm{Bias}=\frac{\sum_{\mathrm{i}=1}^{\mathrm{n}}\left(\mathrm{T}_{\mathrm{i}}-\mathrm{O}_{\mathrm{i}}\right)}{\sum_{\mathrm{i}=1}^{\mathrm{n}} \mathrm{O}_{\mathrm{i}}}(100)$ \\
\hline
\end{tabular}

\section{Results and Discussion}

\subsection{Overall Assessment}

The monthly mean precipitation in the KRB for the period 1998-2014 based on the observations is shown in Figure 1c. Basically, the TMPA-3B43 showed good performance in monthly precipitation estimation, with R and RMSE of 0.75 and $132.41 \mathrm{~mm} /$ month, respectively (Figure 2a). The product slightly overestimated monthly precipitation by $4.28 \%$. For seasonal scale, the best performance was found in DJF, followed by MAM, SON and JJA, with R values ranging from 0.38 to 0.69 (Figure 2). Besides, the TMPA-3B43 slightly overestimated seasonal precipitation by $3.02 \%-8.46 \%$, with the MAM showing the largest overestimation.
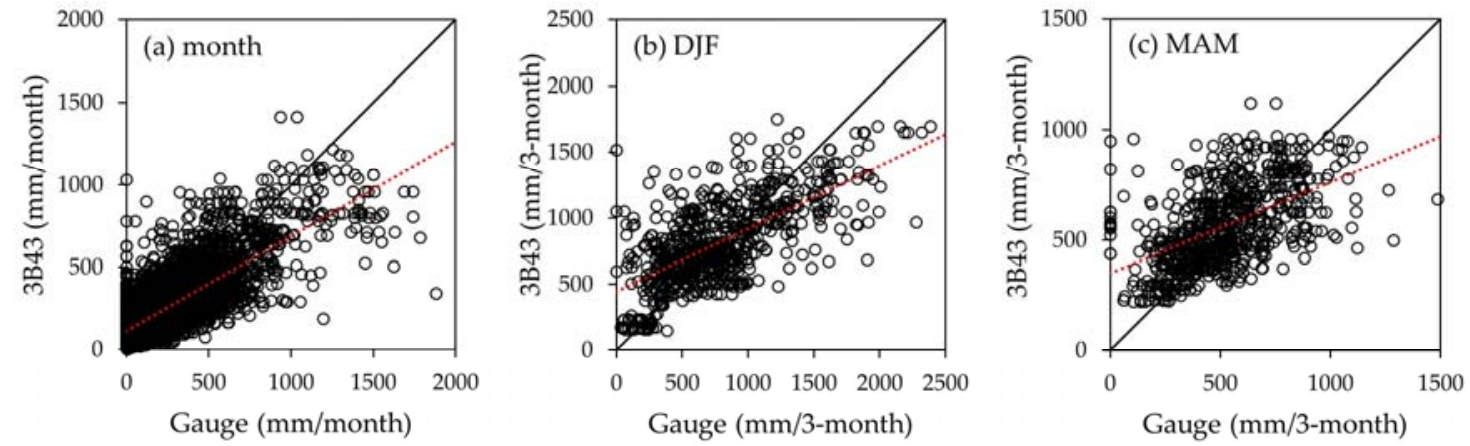

\begin{tabular}{lccc}
\hline & $\mathrm{R}$ & $\operatorname{Bias}(\%)$ & $\mathrm{RMSE}(\mathrm{mm})$ \\
\hline Month & 0.75 & 4.28 & 132.41 \\
DJF & 0.69 & 3.61 & 349.55 \\
MAM & 0.53 & 8.46 & 212.65 \\
JJA & 0.38 & 3.02 & 197.83 \\
SON & 0.52 & 5.16 & 292.23 \\
\hline
\end{tabular}
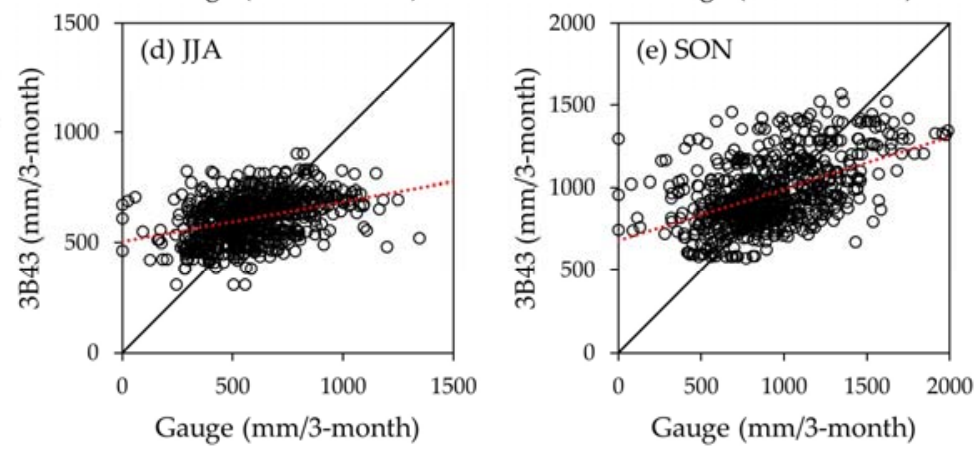

Figure 2. Scatter plots of (a) monthly; (b) December to February; (c) March to May; (d) June to August; and (e) September to November seasonal precipitation derived from the TMPA-3B43 and observations in the Kelantan River Basin between 1998 and 2014.

Overall, the TMPA-3B43 showed better performance for the wet season (e.g., DJF) compared to the dry season (e.g., JJA), which is similar to the findings of Tan et al. [16] and Mahmud et al. [45] that validated TRMM products over Malaysia. This is mainly because the TRMM sensors having better detection capability on a heavy precipitation cloud system which dominates during the NEM. 
By contrast, the poor performance of the TMPA-3B43 in the dry season could be attributed to poor detection capability in light precipitation (less than $3 \mathrm{~mm} /$ day) [46]. Larger RMSE values were found during the wet season (e.g., SON and DJF) because of the scaling up effect of the precipitation rate from an hourly to monthly scale.

The findings are consistent with other studies that found overestimation of TRMM products in the estimation of total precipitation amount $[47,48]$. The bias-corrected TMPA-3B43 product is generated using multiple satellite images and algorithms, as well as the GPCC product. However, the performance of the product is affected by the errors in the satellite sampling technique, precipitation retrieval methods and bias correction algorithms used in the GPCC product development [49]. Therefore, further improvements of the mentioned errors should be conducted in this region, to improve the accuracy of the TMPA-3B43 in monthly and seasonal precipitation estimation.

\subsection{Spatial Assessment}

To further test the research question, the 42 rain gauges with full-time series data from 1998 to 2014 were compared with the TMPA-3B43 individually. Three statistical metrics at monthly scale were used for this spatial analysis (Figure 3). Generally, the TMPA-3B43 had good correlation with the rain gauges located in the northern region, nearer to the coast. By contrast, moderate correlation was found over the mountainous regions in the southwestern part of the basin. The TMPA-3B43 spatial specific-region performance could be due to the fact that spatial resolution $\left(0.25^{\circ}\right)$ is less sensitive to local-scale precipitation events. This is because small-scale and short temporal variation of convective clouds are difficult to detect by the TRMM sensors. In addition, the difficulty of the TRMM sensor algorithms in identifying different cloud types would cause miscalculation of the rain rate [50].

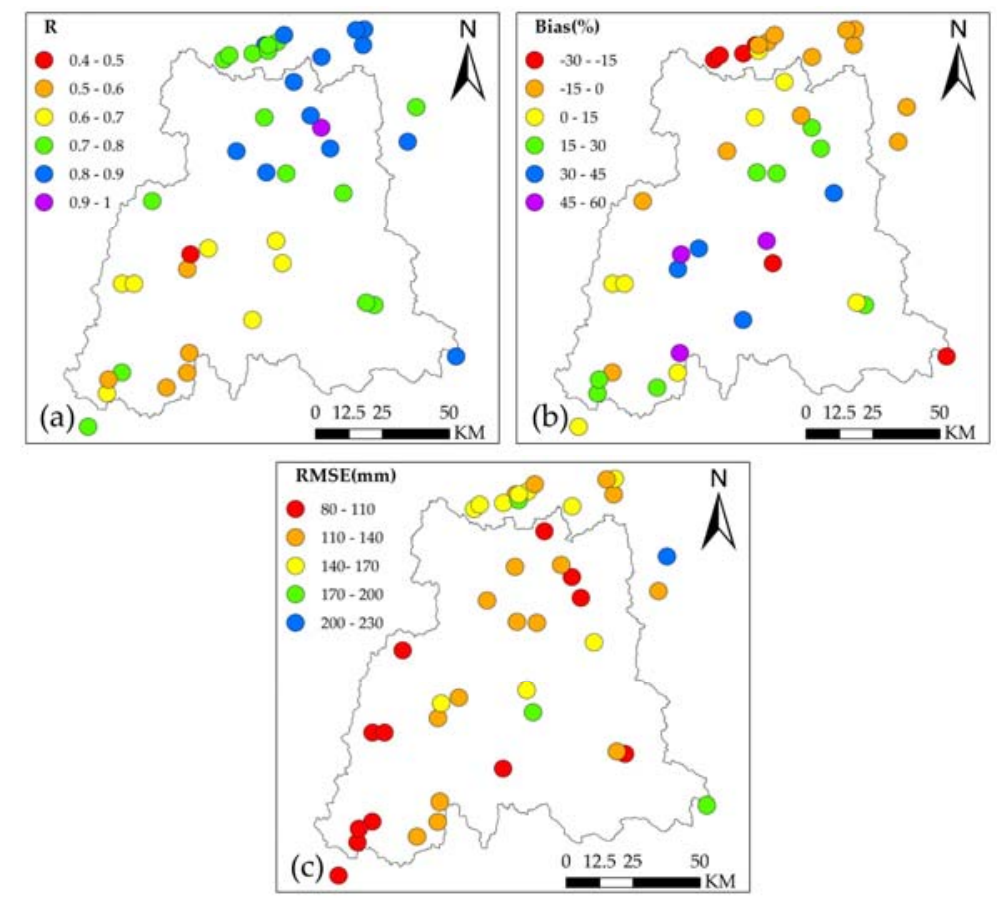

Figure 3. (a) Pearson linear correlation coefficient (R); (b) relative bias (bias) and (c) root mean square error (RMSE) of monthly precipitation between 3B43 and 42 rain gauges over the Kelantan River Basin.

The spatial distributions of $R$ at different seasonal scale over the KRB are presented in Figure 4. The $\mathrm{R}$ between rain gauges and TMPA-3B43 has a distinct geographical pattern for the four seasons, i.e., low $\mathrm{R}$ values were found in the south-eastern region for the JJA, and the south-western region for SON. Interestingly, high R values were generally found in rain gauges that are near to the coastal zone (northern and north-eastern). These regions received higher precipitation amounts due to the 
NEM [16], indicating that TRMM products have better performance in high precipitation regions. While, lower $\mathrm{R}$ values were generally found in central, southern and south-eastern regions, which are characterized with mountainous topography (Figures 1a and 4). This is caused by the incorrect differentiation between non-raining and raining cloud of the thermal infrared over relatively warm cloud that dominates at the high elevation region [51,52]. Besides, differences in the precipitation measurement techniques could also be a cause. For instance, the rain gauge measures precipitation at ground level, while TMPA-3B43 sensors estimate precipitation in the atmosphere. Therefore, the TMPA-3B43 has less accuracy in complex topography regions.
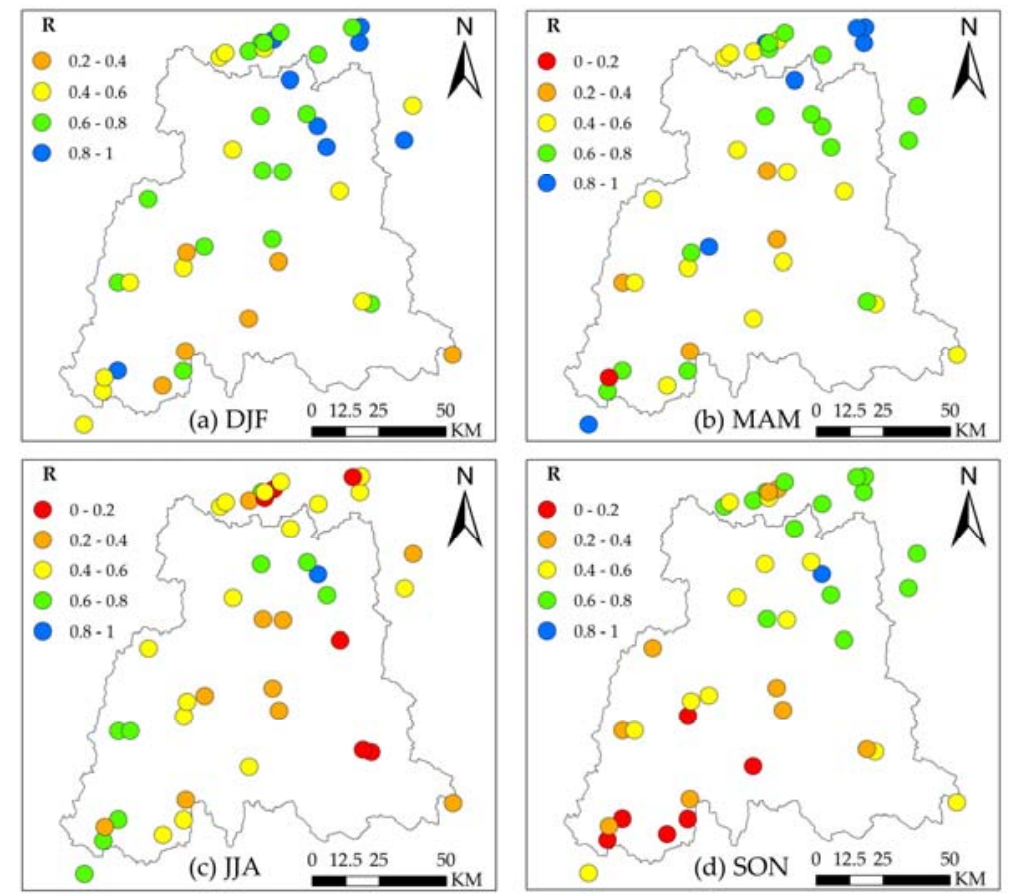

Figure 4. Pearson linear correlation coefficient (R) of (a) December to February; (b) March to May; (c) June to August and (d) September to November seasonal precipitation between the TMPA-3B43 and 42 rain gauges over the Kelantan River Basin.

\subsection{SPI Validation}

Average SPI temporal variability of the TMPA-3B43 and observations at different time-scales over the KRB is illustrated in Figure 5. Similarly, the overall accuracy of the SPI was evaluated using the point-to-pixel method as mentioned in Section 3.3. The SPI time-series between the TMPA-3B43 and observations have moderate correlation for the evaluated time-scales, with the best $\mathrm{R}$ value at SPI-1 $(\mathrm{R}=0.51)$. Basically, shorter SPI time-scales are poor in describing drought occurrence clearly, but can accurately capture the cyclical behavior of the precipitation regime. By contrast, larger time-scales of SPI values (e.g., SPI-12) are more useful in separating the persistent dry and wet periods [23], indicating that the TMPA-3B43 can potentially be used for shorter drought analysis in this region.

The most likely cause of the moderate accuracy of SPI calculations in this study is the impact of precipitation length records on the SPI calculation [53]. This is mainly due to the instability in parameters calculation at shorter time-scales. Ideally, a data period of 30 years is required for SPI calculations, however, this study only evaluated 17 years as the TMPA-3B43 data is only available from 1998 onwards. Another possible explanation for these results may be the lack of adequate rain gauges in the TMPA-3B43 bias correction. After checking the number of stations per grid in the GPCC Full Data Reanalysis product for the period of 1998-2013 [54,55], we found that there are four grids covering the KRB. One rain gauge is located in the northeastern grid, while another three rain gauges 
are located in the southwestern grid. There are no rain gauges in the northwestern and southeastern regions of the basin for the bias correction. Therefore, re-bias correction of the TMPA-3B43 with more rain gauges should be conducted to improve the SPI estimations in this region.

Based on the SPI-3, the extreme drought events (SPI $\leq-2$ ) were clearly detected in 1998, 2004, 2006 and 2012 by the TMPA-3B43 and observations (Figure 5b). Nevertheless, some mismatched in-drought categories were also identified. For instance, the TMPA-3B43 defined the year 2000 as an extreme drought event, while observations only classified it as a severely dry condition. The most striking result to emerge from Figure 5 is that the SPI agrees well in dryness/wetness between conditions in the TMPA-3B43 and observations in the KRB, except for the 2008-2009 period. A possible explanation for this is the scaling footprint problem between a mesoscale gridded product and a rain gauge, which could lead to poor agreement in precipitation quantitative estimation. These results agree with the validation study for TRMM products reported by Tan et al. [16], which showed that satellite products tend to underestimate heavy precipitation amount and to overestimate moderate precipitation amount.
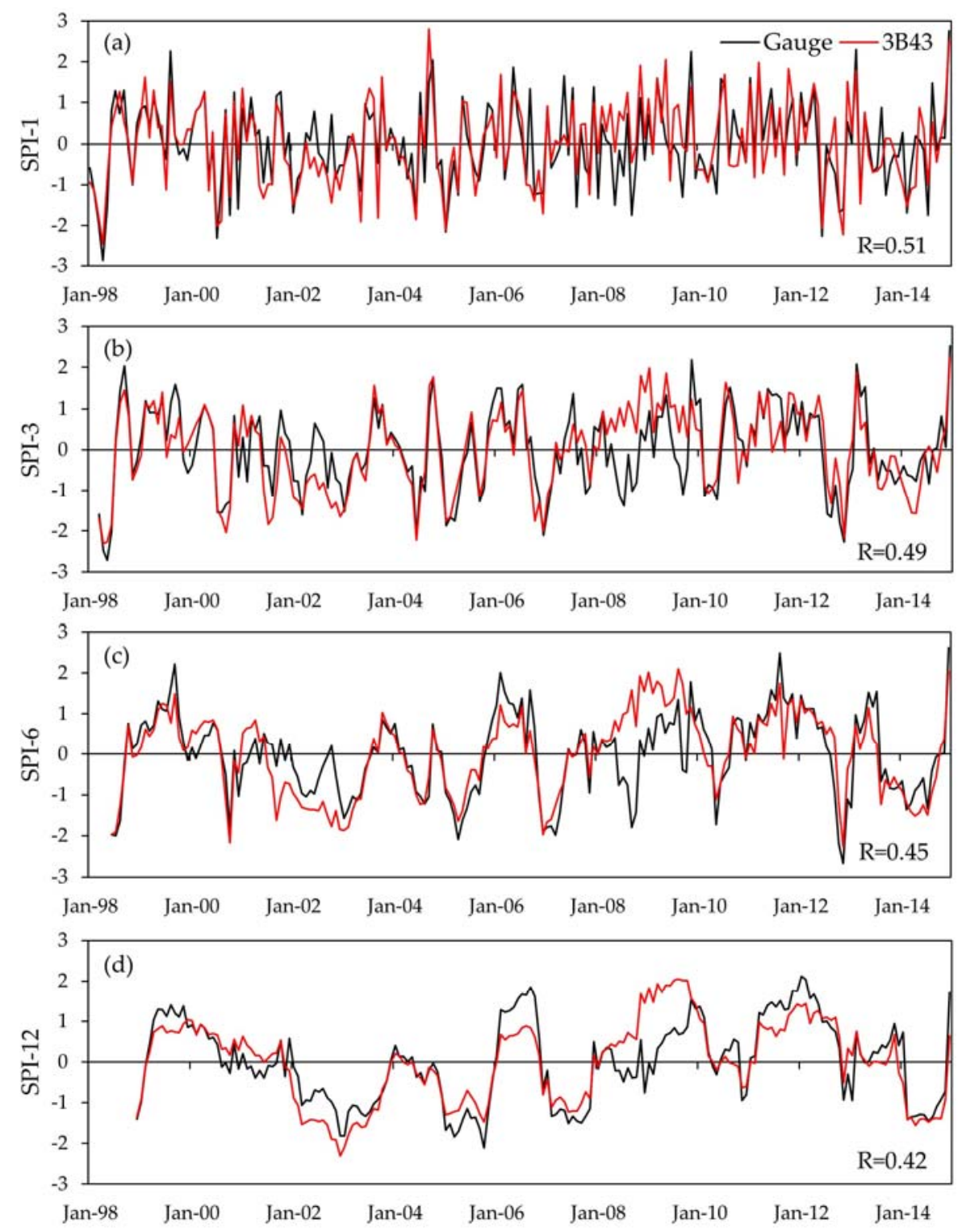

Figure 5. Standardized Precipitation Index (SPI) in the Kelantan River Basin at different time-scales: (a) one-month; (b) three-month; (c) six-month and (d) twelve-month from 1998 to 2014. 
The spatial distribution of $\mathrm{R}$ values in SPI estimations for four different time-scales between the TMPA-3B43 and rain gauges is displayed in Figure 6. The $\mathrm{R}$ values are low in the central, southern and south-eastern regions, while a better agreement was found in the north and north-eastern regions. The results show that the TMPA-3B43 is less reliable in low land area between high mountainous and coastal regions. A possible explanation for these results might be that the heavy precipitation brought by the SWM is drastically decreased by the Titiwangsa range and Sumatra mainland. Therefore, the TMPA-3B43 has difficulty in estimating SPI in the central and southern KRB. As shown in Figure 6, the higher the SPI time-scale, the less stations show good correlation, indicating that the TMPA-3B43 performed better on a shorter SPI time-scale. This finding is similar to that of Tao et al. [22] who found that the TMPA-3B43 had poorer performance with increases of SPI time-scales over the Jiangsu Province, China. This could be due to large RMSE values in longer time-scales, e.g., the seasonal scale RMSE value is greater than the monthly scale (Figure 2).
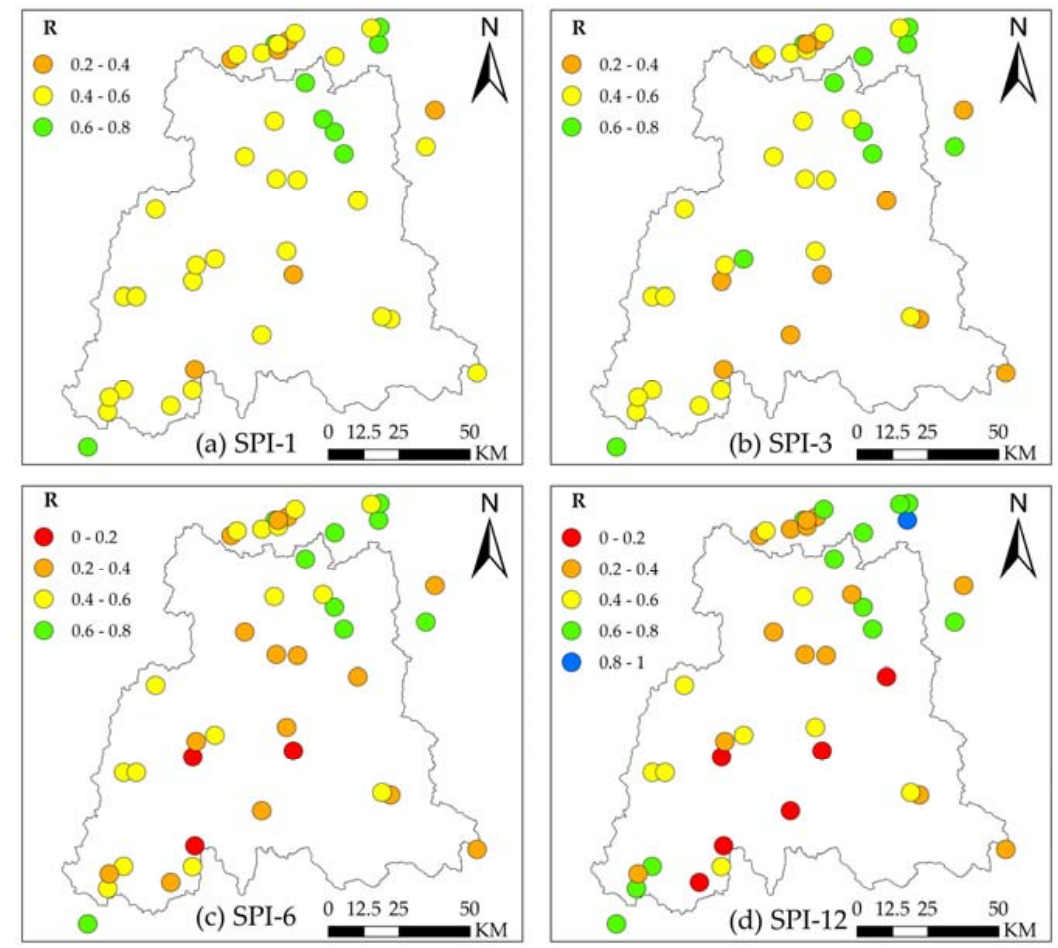

Figure 6. Pearson linear correlation coefficient (R) between SPI of the TMPA-3B43 and rain gauges at time-scales of (a) one-month; (b) three-month; (c) six-month and (d) twelve-month in the Kelantan River Basin.

Different time-scales of SPI in the KRB measured by the TMPA-3B43 and observations are displayed in Figure 7. Besides the occurrence of major drought events, their duration and magnitude can also be clearly identified in Figure 7. Six major meteorological drought periods were identified by both the TMPA-3B43 and observations, which were 1998, 2002-2003, 2004-2005, 2007, 2010 and 2013-2014. The drought events found in the TMPA-3B43 are more intense compared to the observations. This is mainly because the TMPA-3B43 tends to overestimate the total monthly precipitation amount over the KRB as shown in Figure 2. Figure 8 shows that much more severely dry and extreme drought events were found at shorter time-scales of SPI, with a decrease in the number of drought events detected after the SPI-6. These results are consistent with Zhao et al. [56], who reported similar findings in the Xiang Jiang River Basin, China. Besides, the TMPA-3B43 detected the same number of drought events as observations at SPI-3 and SPI-6, 17 and 15 drought events, respectively. This finding suggests that the TMPA-3B43 can be useful to detect drought frequency for the 3-month and 6-month SPI time-scales in the KRB. 

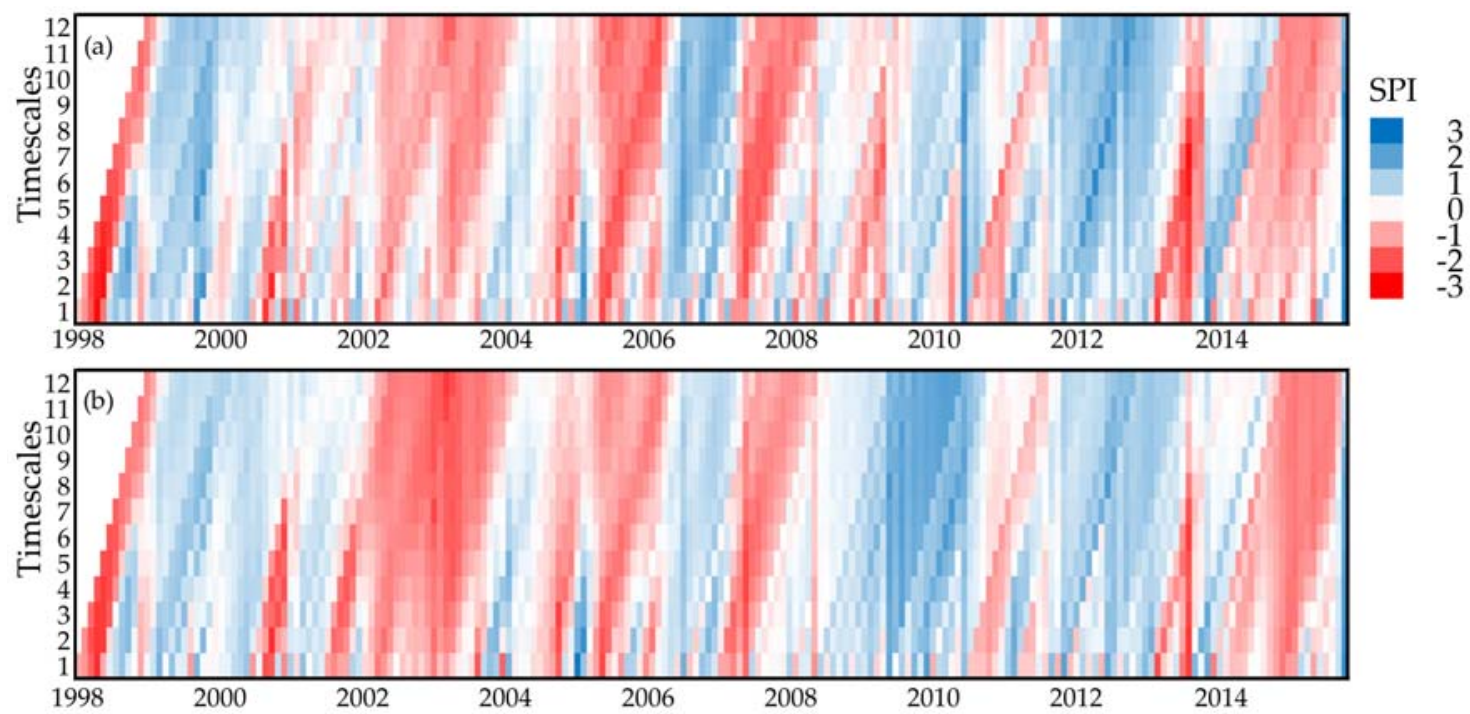

Figure 7. Standardized Precipitation Index (SPI) time series measured from (a) rain gauges and (b) the TMPA-3B43 from one-month to twelve-month time-scales over the Kelantan River Basin from 1998 to 2014.

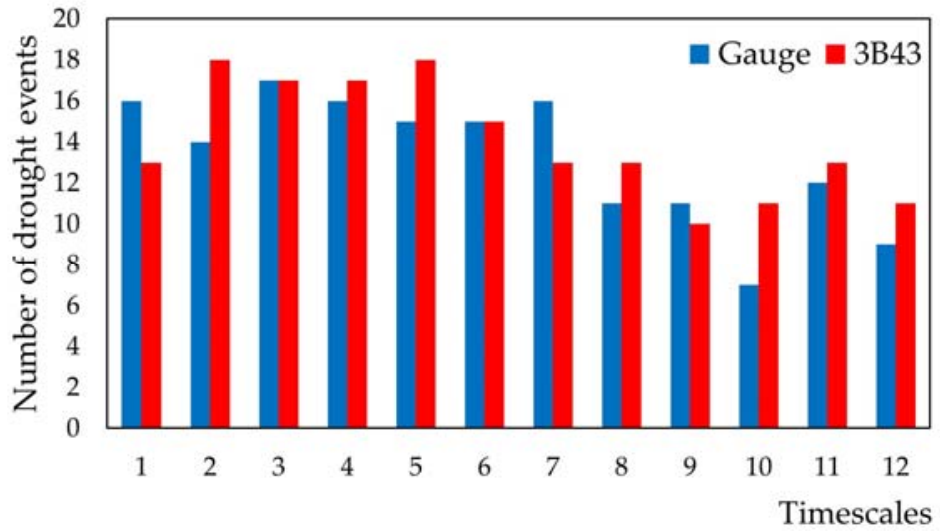

Figure 8. Number of drought events detected by the TMPA-3B43 and observations $(\mathrm{SPI} \leq-1.5)$ over the Kelantan River basin for the period of 1998-2014.

\subsection{The Drought 2014}

A prolonged dry spell occurred in Malaysia in 2014, particularly in the KRB. As shown in Figure 9, monthly drought patterns for the SPI-1 during 2014 indicate that the KRB experienced severely dry to extreme drought conditions in the first four months of the year. The extreme drought is mainly distributed in the northern, eastern and north-eastern regions nearer to the coast, particularly in February and March 2014. This event caused very low water levels in several rivers of the basin, impacting the local population. For example, more than 8000 paddy farmers in Kelantan were affected, with estimated total losses of about USD $\$ 22$ million. In addition, the drought event also affected human health, as the number of dengue fever death cases was three times greater in 2014 than 2013. This is due to the drought situation, which accelerated the life cycle of the Aedes mosquito that transmits the dengue virus to humans.

Drought conditions were reduced from May to November 2014. It can be observed from Figure 9 that drought reduced from extreme severity in February-April to normal climate condition in May-November, with some drought affected regions in the north-eastern region in September. Spatial heterogeneity of the SPI across the KRB was observed in September 2014, where the north-eastern 
region experienced negative anomalies of precipitation, while the south-eastern region had negative values. The month of December 2014 showed extremely wet conditions, resulting in one of the worst flood events in the recent history of Malaysia. Generally, extreme wet conditions were found in the central and northern regions of the basin. More than 230,000 people were evacuated during this flood event, with total damage of about USD $\$ 560$ million and the death of at least 23 people [16].
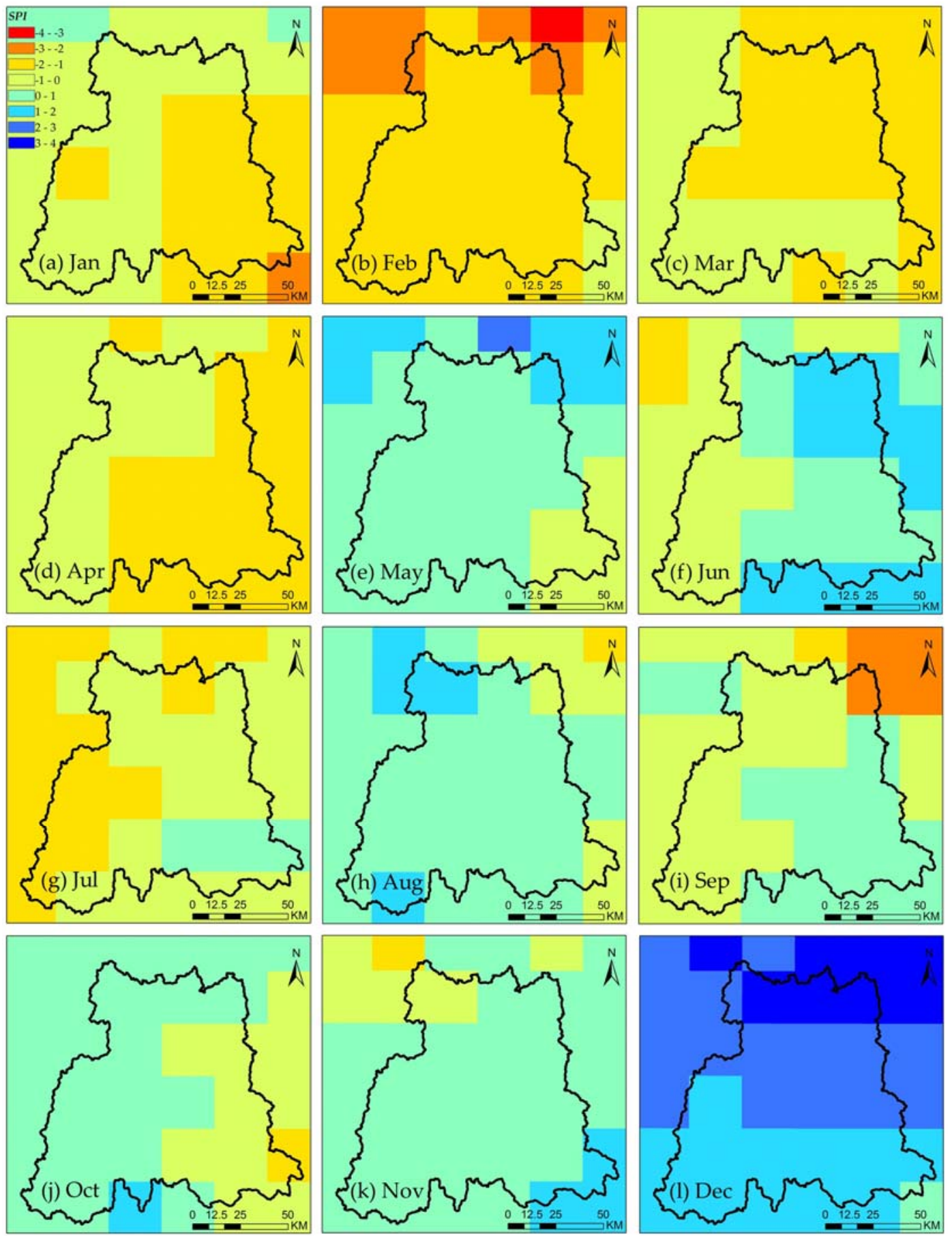

Figure 9. Drought monitoring based on the TMPA-3B43 one-month Standardized Precipitation Index (SPI) for (a) January; (b) February; (c) March; (d) April; (e) May; (f) June; (g) July; (h) August; (i) September; (j) October; (k) November; and (1) December in 2014 in the Kelantan River Basin. 


\section{Conclusions}

The availability of satellite precipitation products (SPPs) offers an alternative source for drought monitoring at global, high spatial and temporal scales. This study assesses the reliability of the TMPA-3B43 product in estimating meteorological drought in the Kelantan River Basin (KRB) from 1998 to 2014. The results are validated with ground observations collected from 42 rain gauges. The standardized precipitation index (SPI) from different time-scales (one to twelve months) was used to evaluate drought conditions in monthly and seasonal scales. The main findings of this study are summarized as follows:

(1) The TMPA-3B43 performed well in estimating monthly precipitation over the KRB, with slight overestimations in total precipitation amount. Overall, the TMPA-3B43 showed better estimation during the northeast monsoon (wet season) compared to the southwest monsoon (dry season).

(2) A distinct spatial pattern can be found for the $\mathrm{R}$ and bias in monthly and seasonal precipitation assessment. Better correlation between the TMPA-3B43 and ground-based observations can be observed in the northern and north-eastern parts of the basin. Larger bias was found in central, southern and south-eastern regions which are characterized by high topography.

(3) The reliability of the TMPA-3B43 in SPI measurement decreases with longer time-scales (e.g., twelve months), showing that the product is more suitable to assess short-term meteorological droughts in Malaysia. Moreover, the drought events measured by the TMPA-3B43 are more intense than the observations one.

(4) More severe drought events were found at shorter SPI time-scales (e.g., SPI-1). The TMPA-3B43 matched well in identifying most of the drought events in the KRB at various time-scales, except for the 2008-2009 period. However, the same number of drought events was observed at the SPI-3 and SPI-6 time-scales.

In general, the TMPA-3B43 is capable of monitoring the temporal variation of the drought conditions in tropical regions, but the accuracy of the drought intensity estimation is still insufficient. This product has potential to be used for other hydro-climatic related applications such as hydrological modelling [57]. Further work is needed to validate the performance of TRMM products in other extreme precipitation indices that are recommended by the Expert Team on Climate Change Detection and Indices (ETCCDI) [58]. Moreover, future research could explore the improvement of drought monitoring by SPPs, such as new satellite retrieval algorithms, new satellite-based drought index, and re-calibration with ground-based observations.

Supplementary Materials: The following are available online at www.mdpi.com/2073-4441/9/1/57/s1.

Acknowledgments: This research was supported by the Universiti Sains Malaysia short-term grant (grant No.: 304/PFIZIK/6313260). The authors wish to thank the Meteorological Department Malaysia, Department of Irrigation and Drainage Malaysia and Tropical Rainfall Measuring Mission (TRMM) Multisatellite Precipitation Analysis (TMPA) developers for providing the climate data. Constructive comments from Arthur P. Cracknell, $\mathrm{K}$. Brindha and three anonymous reviewers are acknowledged.

Author Contributions: Mou Leong Tan collected, processed and analyzed the data, and drafted the manuscript. Kok Chooi Tan, Vivien P. Chua and Ngai Weng Chan made contributions in editing of the manuscript.

Conflicts of Interest: The authors declare no conflict of interest.

\section{References}

1. Dai, A.G. Drought under global warming: A review. Wiley Interdiscip. Rev. Clim. Chang. 2011, 2, 45-65. [CrossRef]

2. Bonal, D.; Burban, B.; Stahl, C.; Wagner, F.; Hérault, B. The response of tropical rainforests to droughtLessons from recent research and future prospects. Ann. For. Sci. 2016, 73, 27-44. [CrossRef] [PubMed]

3. Tan, M.L.; Ficklin, D.L.; Ibrahim, A.L.; Yusop, Z. Impacts and uncertainties of climate change on streamflow of the Johor River Basin, Malaysia using a CMIP5 General Circulation Model ensemble. J. Water Clim. Chang. 2014, 5, 676-695. [CrossRef] 
4. $\quad$ Laan-Luijkx, I.T.; Velde, I.R.; Krol, M.C.; Gatti, L.V.; Domingues, L.G.; Correia, C.S.C.; Miller, J.B.; Gloor, M.; Leeuwen, T.T.; Kaiser, J.W.; et al. Response of the Amazon carbon balance to the 2010 drought derived with carbontracker South America. Glob. Biogeochem. Cycles 2015, 29, 1092-1108. [CrossRef]

5. Corlett, R.T. The impacts of droughts in tropical forests. Trends Plant Sci. 2016, 21, 584-593. [CrossRef] [PubMed]

6. Thomas, J.; Prasannakumar, V. Temporal analysis of rainfall (1871-2012) and drought characteristics over a tropical monsoon-dominated state (Kerala) of India. J. Hydrol. 2016, 534, 266-280. [CrossRef]

7. Lewis, S.L.; Brando, P.M.; Phillips, O.L.; van der Heijden, G.M.F.; Nepstad, D. The 2010 Amazon drought. Science 2011, 331, 554. [CrossRef] [PubMed]

8. Nakagawa, M.; Tanaka, K.; Nakashizuka, T.; Ohkubo, T.; Kato, T.; Maeda, T.; Sato, K.; Miguchi, H.; Nagamasu, H.; Ogino, K.; et al. Impact of severe drought associated with the 1997-1998 El Nino in a tropical forest in Sarawak. J. Trop. Ecol. 2000, 16, 355-367. [CrossRef]

9. Field, R.D.; van der Werf, G.R.; Fanin, T.; Fetzer, E.J.; Fuller, R.; Jethva, H.; Levy, R.; Livesey, N.J.; Luo, M.; Torres, O; ; et al. Indonesian fire activity and smoke pollution in 2015 show persistent nonlinear sensitivity to El Nino-induced drought. Proc. Natl. Acad. Sci. USA 2016, 113, 9204-9209. [CrossRef] [PubMed]

10. Marengo, J.A.; Alves, L.M.; Soares, W.R.; Rodriguez, D.A.; Camargo, H.; Riveros, M.P.; Pabló, A.D. Two contrasting severe seasonal extremes in tropical South America in 2012: Flood in amazonia and drought in northeast Brazil. J. Clim. 2013, 26, 9137-9154. [CrossRef]

11. McKee, T.B.; Doesken, N.J.; Kleist, J. The relationship of drought frequency and duration to time scales. In Proceedings of the 8th Conference on Applied Climatology, Anaheim, CA, USA, 17-22 January 1993; American Meteorological Society: Anaheim, CA, USA, 1993; pp. 179-183.

12. Chen, J.F.; Huang, Z.Y.; Jin, Q.J. SPI-based drought characteristics analysis and prediction for Xiqiao station in Yunnan province, China. Disaster Adv. 2012, 5, 1260-1268.

13. Karavitis, C.A.; Alexandris, S.; Tsesmelis, D.E.; Athanasopoulos, G. Application of the Standardized Precipitation Index (SPI) in Greece. Water 2011, 3, 787-805. [CrossRef]

14. Rahman, M.R.; Lateh, H. Meteorological drought in bangladesh: Assessing, analysing and hazard mapping using SPI, GIS and monthly rainfall data. Environ. Earth Sci. 2016, 75, 1-20. [CrossRef]

15. Li, C.; Wang, R. Recent changes of precipitation in Gansu, northwest China: An index-based analysis. Theor. Appl. Climatol. 2016, 1-16. [CrossRef]

16. Tan, M.L.; Ibrahim, A.L.; Duan, Z.; Cracknell, A.P.; Chaplot, V. Evaluation of six high-resolution satellite and ground-based precipitation products over Malaysia. Remote Sens. 2015, 7, 1504-1528. [CrossRef]

17. Worqlul, A.W.; Maathuis, B.; Adem, A.A.; Demissie, S.S.; Langan, S.; Steenhuis, T.S. Comparison of rainfall estimations by TRMM 3B42, MPEG and CFSR with ground-observed data for the Lake Tana Basin in Ethiopia. Hydrol. Earth Syst. Sci. 2014, 18, 4871-4881. [CrossRef]

18. Piani, C.; Weedon, G.P.; Best, M.; Gomes, S.M.; Viterbo, P.; Hagemann, S.; Haerter, J.O. Statistical bias correction of global simulated daily precipitation and temperature for the application of hydrological models. J. Hydrol. 2010, 395, 199-215. [CrossRef]

19. Serrat-Capdevila, A.; Merino, M.; Valdes, J.; Durcik, M. Evaluation of the performance of three satellite precipitation products over Africa. Remote Sens. 2016, 8, 836. [CrossRef]

20. Maggioni, V.; Meyers, P.C.; Robinson, M.D. A review of merged high-resolution satellite precipitation product accuracy during the Tropical Rainfall Measuring Mission (TRMM) era. J. Hydrometeorol. 2016, 17, 1101-1117. [CrossRef]

21. Chen, F.; Li, X. Evaluation of IMERG and TRMM 3B43 monthly precipitation products over mainland China. Remote Sens. 2016, 8, 472. [CrossRef]

22. Tao, H.; Fischer, T.; Zeng, Y.; Fraedrich, K. Evaluation of TRMM 3B43 precipitation data for drought monitoring in Jiangsu province, China. Water 2016, 8, 13. [CrossRef]

23. De Jesus, A.; Brena-Naranjo, J.A.; Pedrozo-Acuna, A.; Yamanaka, V.H.A. The use of TRMM 3 B42 product for drought monitoring in Mexico. Water 2016, 8, 18. [CrossRef]

24. Li, X.H.; Zhang, Q.; Ye, X.C. Dry/wet conditions monitoring based on TRMM rainfall data and its reliability validation over Poyang Lake Basin, China. Water 2013, 5, 1848-1864. [CrossRef]

25. Zeng, H.W.; Li, L.J.; Li, J.Y. The evaluation of TRMM multisatellite precipitation analysis (TMPA) in drought monitoring in the Lancang River Basin. J. Geogr. Sci. 2012, 22, 273-282. [CrossRef] 
26. Okonkwo, C.; Demoz, B.; Onyeukwu, K. Characteristics of drought indices and rainfall in Lake Chad Basin. Int. J. Remote Sens. 2013, 34, 7945-7961. [CrossRef]

27. Vernimmen, R.R.E.; Hooijer, A.; Aldrian, E.; van Dijk, A. Evaluation and bias correction of satellite rainfall data for drought monitoring in Indonesia. Hydrol. Earth Syst. Sci. 2012, 16, 133-146. [CrossRef]

28. Paridal, B.R.; Collado, W.B.; Borah, R.; Hazarika, M.K.; Sarnarakoon, L. Detecting drought-prone areas of rice agriculture using a MODIS-derived soil moisture index. GISci. Remote Sens. 2008, 45, 109-129. [CrossRef]

29. Yaduvanshi, A.; Srivastava, P.K.; Pandey, A.C. Integrating TRMM and MODIS satellite with socio-economic vulnerability for monitoring drought risk over a tropical region of India. Phys. Chem. Earth Parts A/B/C 2015, 83-84, 14-27. [CrossRef]

30. Tan, M.L.; Ibrahim, A.B.; Cracknell, A.P.; Yusop, Z. Changes in precipitation extremes over the Kelantan River Basin, Malaysia. Int. J. Climatol. 2016, in press. [CrossRef]

31. Yusof, F.; Hui-Mean, F.; Suhaila, J.; Yusof, Z. Characterisation of drought properties with bivariate copula analysis. Water Resour. Manag. 2013, 27, 4183-4207. [CrossRef]

32. Hashim, M.; Reba, N.M.; Nadzri, M.I.; Pour, A.B.; Mahmud, M.R.; Mohd Yusoff, A.R.; Ali, M.I.; Jaw, S.W.; Hossain, M. Satellite-based run-off model for monitoring drought in Peninsular Malaysia. Remote Sens. 2016, 8, 633. [CrossRef]

33. Becker, A.; Schneider, U.; Meyer-Christoffer, A.; Ziese, M.; Finger, P.; Stender, P.; Heller, A.; Breidenbach, J.N. GPCC Report for Years 2009, 2010 and 2011. Available online: https:/ /www.dwd.de/EN/ourservices/gpcc/ reports_publications/home_reports_publications.html (accessed on 11 August 2016).

34. Huffman, G.J.; Adler, R.F.; Bolvin, D.T.; Gu, G.J.; Nelkin, E.J.; Bowman, K.P.; Hong, Y.; Stocker, E.F.; Wolff, D.B. The TRMM Multisatellite Precipitation Snalysis (TMPA): Quasi-global, multiyear, combined-sensor precipitation estimates at fine scales. J. Hydrometeorol. 2007, 8, 38-55. [CrossRef]

35. Goddard Earth Sciences Data and Information Services Center. Available online: http://mirador.gsfc.nasa.gov (accessed on 8 July 2016).

36. National Drought Mitigation Center. Available online: http://drought.unl.edu/monitoringtools/ downloadablespiprogram.aspx (accessed on 25 July 2016).

37. Thiemig, V.; Rojas, R.; Zambrano-Bigiarini, M.; Levizzani, V.; De Roo, A. Validation of satellite-based precipitation products over sparsely gauged African river basins. J. Hydrometeorol. 2012, 13, 1760-1783. [CrossRef]

38. Wang, W.; Lu, H.; Yang, D.W.; Sothea, K.; Jiao, Y.; Gao, B.; Peng, X.T.; Pang, Z.G. Modelling hydrologic processes in the Mekong River Basin using a distributed model driven by satellite precipitation and rain gauge observations. PLoS ONE 2016, 11, e0152229. [CrossRef] [PubMed]

39. Yang, Y.; Luo, Y. Evaluating the performance of remote sensing precipitation products CMORPH, PERSIANN, and TMPA, in the arid region of northwest China. Theor. Appl. Climatol. 2014, 118, 429-445. [CrossRef]

40. Khan, S.I.; Hong, Y.; Gourley, J.J.; Khattak, M.U.K.; Yong, B.; Vergara, H.J. Evaluation of three high-resolution satellite precipitation estimates: Potential for monsoon monitoring over Pakistan. Adv. Space Res. 2014, 54, 670-684. [CrossRef]

41. Dembélé, M.; Zwart, S.J. Evaluation and comparison of satellite-based rainfall products in Burkina Faso, West Africa. Int. J. Remote Sens. 2016, 37, 3995-4014. [CrossRef]

42. Tangang, F.T.; Juneng, L. Mechanisms of Malaysian rainfall anomalies. J. Clim. 2004, 17, 3616-3622. [CrossRef]

43. Tan, M.L.; Ficklin, D.L.; Dixon, B.; Ibrahim, A.L.; Yusop, Z.; Chaplot, V. Impacts of DEM resolution, source, and resampling technique on SWAT-simulated streamflow. Appl. Geogr. 2015, 63, 357-368. [CrossRef]

44. Yang, X.Q.; Yong, B.; Hong, Y.; Chen, S.; Zhang, X.H. Error analysis of multi-satellite precipitation estimates with an independent raingauge observation network over a medium-sized humid basin. Hydrol. Sci. J. 2016, 61, 1813-1830. [CrossRef]

45. Mahmud, M.R.; Numata, S.; Matsuyama, H.; Hosaka, T.; Hashim, M. Assessment of effective seasonal downscaling of TRMM precipitation data in Peninsular Malaysia. Remote Sens. 2015, 7, 4092-4111. [CrossRef]

46. Pipunic, R.C.; Ryu, D.; Costelloe, J.F.; Su, C.H. An evaluation and regional error modeling methodology for near-real-time satellite rainfall data over Australia. J. Geophys. Res. Atmos. 2015, 120, 767-783. [CrossRef]

47. Adeyewa, Z.D.; Nakamura, K. Validation of TRMM radar rainfall data over major climatic regions in Africa. J. Appl. Meteorol. 2003, 42, 331-347. [CrossRef] 
48. Curtarelli, M.P.; Renno, C.D.; Alcantara, E.H. Evaluation of the tropical rainfall measuring mission 3B43 product over an inland area in Brazil and the effects of satellite boost on rainfall estimates. J. Appl. Remote Sens. 2014, 8, 083589. [CrossRef]

49. Duan, Z.; Liu, J.; Tuo, Y.; Chiogna, G.; Disse, M. Evaluation of eight high spatial resolution gridded precipitation products in Adige Basin (Italy) at multiple temporal and spatial scales. Sci. Total Environ. 2016, 573, 1536-1553. [CrossRef] [PubMed]

50. Wolff, D.B.; Marks, D.A.; Amitai, E.; Silberstein, D.S.; Fisher, B.L.; Tokay, A.; Wang, J.; Pippitt, J.L. Ground validation for the Tropical Rainfall Measuring Mission (TRMM). J. Atmos. Ocean. Technol. 2005, 22, 365-380. [CrossRef]

51. Dinku, T.; Ceccato, P.; Grover-Kopec, E.; Lemma, M.; Connor, S.J.; Ropelewski, C.F. Validation of satellite rainfall products over East Africa's complex topography. Int. J. Remote Sens. 2007, 28, 1503-1526. [CrossRef]

52. Hirpa, F.A.; Gebremichael, M.; Hopson, T. Evaluation of high-resolution satellite precipitation products over very complex terrain in Ethiopia. J. Appl. Meteorol. Climatol. 2010, 49, 1044-1051. [CrossRef]

53. Wu, H.; Hayes, M.J.; Wilhite, D.A.; Svoboda, M.D. The effect of the length of record on the standardized precipitation index calculation. Int. J. Climatol. 2005, 25, 505-520. [CrossRef]

54. Huffman, G.J.; Bolvin, D.T. TRMM and Other Data Precipitation Data Set Documentation. 2014. Available online: https://pmm.nasa.gov/data-access/downloads (accessed on 11 August 2016).

55. Schneider, U.; Becker, A.; Finger, P.; Meyer-Christoffer, A.; Rudolf, B.; Ziese, M. GPCC Full Data Reanalysis Version 7.0 at $1.0^{\circ}$ : Monthly Land-Surface Precipitation from Rain-Gauges Built on GTS-Based and Historic Data; Global Precipitation Climatology Centre: Offenbach am Main, Germany, 2015.

56. Zhao, L.; Wu, J.J.; Fang, J. Robust response of streamflow drought to different timescales of meteorological drought in Xiangjiang River Basin of China. Adv. Meteorol. 2016, 8, 1634787. [CrossRef]

57. Tan, M.L.; Ibrahim, A.L.; Yusop, Z.; Duan, Z.; Ling, L. Impacts of land-use and climate variability on hydrological components in the Johor River Basin, Malaysia. Hydrol. Sci. J. 2015, 60, 873-889. [CrossRef]

58. Karl, T.R.; Nicholls, N.; Ghazi, A. Clivar/GCOS/WMO workshop on indices and indicators for climate extremes workshop summary. Clim. Chang. 1999, 42, 3-7. [CrossRef]

(C) 2017 by the authors; licensee MDPI, Basel, Switzerland. This article is an open access article distributed under the terms and conditions of the Creative Commons Attribution (CC-BY) license (http:/ / creativecommons.org/licenses/by/4.0/). 